\title{
Research on the Factors Affecting the Working Competence of Football Coaches in Colleges and Universities
}

\author{
Chen Wang \\ Xi'an Fanyi University \\ Xi'an, China
}

\begin{abstract}
This research starts from the perspective of coaching ability of football coaches of colleges and universities in China, and carries out an overall analysis for the current status of coaches' teaching ability, so as to strengthen the coaching ability of football coaches in colleges and universities, enhance the development level of college football in China, and promote the level of socialization of football in China. It also provides a scientific and effective practice and theoretical basis for the teaching, training and scientific research of college football projects in China, and has a certain reference for improving the football level of colleges and universities in China. Football coaches occupy an important position in college football teaching, so their coaching ability directly determines the quality of college football teaching. However, there are many factors that affect the coaching ability in the actual work of football coaches in colleges and universities. Therefore, football coaches in colleges and universities must adopt effective measures to improve their coaching ability on the basis of the analysis of the factors affecting their coaching ability, so as to improve the quality of college football teaching.
\end{abstract}

Keywords-football coaches in colleges and universities; working ability; influencing factors

\section{INTRODUCTION}

\section{A. Research Object}

The evaluation standard of coaching ability of football coaches in colleges and universities in China shall be as the research object.

\section{B. Research Method}

A total of 100 questionnaires are distributed, and 97 questionnaires are collected, with a recovery rate of $99.5 \%$ and an effective rate of $100 \%$. The content of questionnaire includes influencing factors, commanding competition factors, management factors, communication and collaboration skills, scientific research factors, and mutual collaboration ability. The questionnaires has discussed the above factors and carried out statistical and analysis for the obtained data information.

\section{RESULTS AND ANALYSIS}

\section{A. Influencing Factors of Specialized Training}

The coaching ability of football coaches in colleges and universities is affected by various factors in specialized training which is an inevitable condition for football training. Before the training activities, football coaches must formulate detailed activity plans, clarify the goals, training elements and competition matters, and rationally and scientifically build the football sport project based on the requirements of football teaching materials and player' own quality conditions. Moreover, football coaches must make a comprehensive plan, comply with the principles, improve the effectiveness of the plan, arrange the players to study the training plan according to time, period and curriculum planning, and set certain training goals. While making the training plan, we cannot design training methods only based on training goals, or it will lead to the waste of talents and resources and affect the improvement of the quality of football training teaching in colleges and universities. Therefore, football coaches in colleges and universities must strictly and accurately determine the problem so as to avoid unreasonable planning and improve the scientificity and rationality of the training plan.

1) Experience of competitions: Football coaches in colleges and universities should possess certain conclusion ability in training, and master enough competition experience. If coaches lack certain competition experience and cannot do a good job, it is difficult for them to find out the problems that athletes have in football training, and then they cannot take an effective way to improve the practice of the football training program. Therefore, football trainers must pay attention to the summary work of training, master enough competition experience, and improve their coaching ability.

2) The application of training methods: At present, most youth football player in China are school students, and what they have received is amateur training. In vide of this feature, football trainers are required to fully consider the students' learning and training. Only by fully grasping the football training methods and innovating teaching methods can coaches continuously improve the quality of teaching. The training methods and athletic ability possessed by college 
football coaches affect their coaching ability, and this is because football training ability is the basis for measuring the coaches' working level. Meanwhile, the applying ability of football training skills is more important. Coaches are required to apply various training methods to practical training, carry out reform and innovation, and enhance the enthusiasm for training work. They should scientifically and rationally arrange the players' training time, and improve their training effect.

3) Comprehensive quality judgment ability: Football coaches in colleges and universities must possess comprehensive quality judgment ability, judge players' football training reaction, formulate training methods in a targeted manner, pay attention to the training level of each player in the training, and improve their own coaching ability. The training time for college students in colleges and universities is four years, and they will leave the training institutions after graduation. Therefore, the coaches need to build a step-shaped football team, do a good job in the connection of the new and old player, train more excellent football players, and enhance the strength of the team. At the same time, they must pay attention to the development and construction of college football teams and stabilize the happiness brought by football in college life.

4) Sports demonstration: Football coaches in colleges and universities must have the ability to demonstrate sports. In practical course training, they can guide the players by words and deeds, and provide them with football action skills demonstration, tactical coordination action demonstration, and exercise. Therefore, coaches must have strict requirements for their own movement improvement, constantly learn new teaching knowledge, and establish a good image, and enhance the coaching prestige.

\section{B. Factors of Commanding Match}

During the usual commanding training and match, football coaches in colleges and universities must have reasonable and scientific capabilities of pre-match decision-making, acting according to circumstance and psychological prevention and control. In case of emergency, they also need to have a clear language organization and expression ability to improve the commanding level of football match.

1) Analysis of on-the-spot strain capacity: In the football match, coaches' on-the-spot strain capacity is relatively important. They need to fully analyze the match situation, grasp the match situation, clarify the opponent's game tactical intentions, timely judge the opponent's tactical layout, and then adjust their strategic change plans of their own players in the football stadium, so as to achieve the desired results. What's more, coaches need to scientifically analyze the strengths and weaknesses of their own players in the match, relieve the pressure and contradiction of the match, encourage the players to concentrate on listening to the command. During the halftime, they should flexibly arrange the players to overcome various problems on the battlefield and improve the team's ability to compete.

2) Pre-match decision making ability: The decisionmaking ability before the football match is particularly important. The coaches must pay attention to the planning work before the game, analyze the battlefield situation from opponents, collect and understand the game information of other parties in time, formulate a perfect tactics for football team, and improve their competition ability with the active cooperation of the player. At the same time, the coaches should also put emphasis on the technical mastery situation of the lead players, formulate targeted game strategies, clarify the main lineup of football matches, and lay a solid foundation to improve the preparations for pre-match decision-making.

3) Psychological self-control ability: Football coaches must have a certain psychological control ability to properly adjust the athlete's emotions while reducing the pressure of his own from the match. Most football matches on the spot are relatively fierce. Therefore, the coaches must inspire player' morale and self-confidence, so as to avoid their emotional instability under strong stimulation. At the same time, the coaches must also control their own state and improve the quality of commanding the match, so as not to affect the player' behavior in match, and avoid failing to achieve the expected results. Therefore, the colleges must also pay attention to the psychological morality and thought morals training of football coaches, and require coaches to maintain a clear-headed mind and take a tense situation calmly during the football match.

4) Language expression ability: Football coaches in colleges and universities must have certain language expression and organization ability, because they are required to organize accurate language to command the player on the spot during the fierce competition. The time of pause break in football match is rather short, therefore, the coaches need to quickly organize the language, arrange the deliberate tactics, and convey the combat intention to the player to ensure that the player better understand the game tactics and reach the ideal state. At the same time, if there is some noise during the halftime of the match, the coach must intellectually analyze the tactics and ensure the clarity of the language. In addition, during the competition, coaches need to use language arts to encourage player to participate in the competition and enhance their self-confidence.

\section{Management Factor}

Football coaches in colleges and universities often have more sports experience and professional theoretical level, and play a central role in the development of college football activity. The coaching capabilities of football coaches in colleges and universities will be affected by management factors, including coaching ability and management ability. Therefore, coaches must face up to the management and the influence brought by management factors and improve their management capabilities. 
1) Coaching ability: The coaching ability of football coaches is to adopt the system to restrain player' behavior in training, implement various management objectives in strict accordance with disciplined regulations and the content of rewards and punishments. In addition, the coaches should also carry out ideological and moral education for the player, and avoid the excessive verbal criticism education that affects the player' self-esteem. Instead, they should use the ideological and political education concept to improve the player' selfconfidence and make them regain their confidence in the sports field. Meanwhile, it is necessary to improve the training for coaches' moral attainment, so as to meet the requirements of modern quality science education.

2) Ability of fair management: In daily management work, the football coaches in colleges and universities should pay attention to fairness and impartiality, and treat every player seriously and treat them equally without discrimination. Some coaches solely pay much attention to the main players of the football team, and even some serious unfair treatment phenomenon exists, therefore, it causes that other players have lower interest in football activities. Therefore, football coaches in colleges and universities should establish a correct sense of treatment and adhere to the fair and just leadership concept. According to the various situations of different player, the coaches should formulate different targeted training program and goals, improve their team's ability, and thus enhance their ability to coach.

3) Cognitive ability: Football coaches in colleges and universities must have certain judgment ability for the cognition and understanding of football training. According to the characteristics of football training, they should correctly guide the player, which plays a certain role in the development of good training habits, clarify the relationship between players and football training and improve their work ability. Football coaches should be fully acquainted with various football training subjects. Before the competition, they should sum up the objective laws of daily training and form a deep cognitive concept. At the same time, it is necessary for them to combine campus culture with football training properly to build a good atmosphere and create a football training atmosphere.

4) Innovation ability: Football coaches should have the ability to innovate and develop, accumulate working experience, after finding problems, sum up experience and lessons, and comprehensively innovate football training courses. First of all, coaches must have good and meticulous thinking analysis ability, and a strong self-observation ability. By learning from other successful experience and summary, they reform and innovate the traditional training mode, and ensure that the football training method is in line with the development direction of the team, so as to improve players' ability. Second, football coaches need to draw a new work conclusion according to usual practice process, master new rules of movement, and formulate more perfect football tactics plan, so as to improve their ability to coach.

\section{Communication and Collaboration Ability}

Good communication and cooperation ability is very important for players, and it is the premise and basis for physical and mental health and personal development. In football training, coaches should establish an equal relationship with the players, and they should trust each other, so as to create a good football style. It requires our coaches, players and team members to have a more comprehensive and profound understanding of team spirit and integrate personal survival into team development. They should exert team spirit and mutually help each other to reach the largest work efficiency, try their best to play in different position and coordinate with other players.

1) Colleague collaboration ability: In the normal working life, football coaches should deal with the relations with others. During daily training, they should cooperate with the staff of other departments to improve their coaching ability while coordinating the relationship.

2) Teamwork ability: In the usual football training, football coaches need to establish an equal constraint relationship with the players to ensure mutual trust between the players, master players' training state and the living condition, and give them support under a reasonable circumstance. At the same time, coaches need to improve coordination among players, and enhance team cohesion, thus improving the teamwork. The implementation of team tactics cannot be separated from the coaches' mature technical guidance, and the players must abandon individualism. Only by integrating themselves into this team tactic can personal skills be displayed. While in the football match, the overall strength must be exerted to demonstrate their combat effectiveness.

\section{E. Factors of Scientific Research}

Football coaches should frequently consult a large number of domestic and foreign materials, use relevant scientific research results to improve their abilities, reasonably and scientifically apply various scientific research results, to improve their own teaching ability. Coaches can improve their self-training methods by learning scientific research results, and boldly and decisively apply them to their own football team training. Next, it not only stimulates players' interest in football, but also improves their ability to coach. Finally, coaches have verified the achievements of scientific research in practice and played the role of science and technology in China.

\section{F. Factors of Independent Learning}

The study of cultural knowledge is the necessary and most important way to shape and give play to the comparative advantage of coaches. Football coaches must have a good habit of autonomous learning ability, actively study computer related professional knowledge, use computer to carry out football training activities, and improve the efficiency of football training. Moreover, coaches must have a certain foreign reading ability, which is conducive to summarizing the 
related training experience of other football majors by consulting books and domestic and foreign articles.

\section{CONCLUSION AND RATIONAL ADVICE}

\section{A. Conclusion}

During normal working hours, football coaches should seriously take their own coaching ability, adopt scientific decision-making methods and corresponding plans, and fully devote themselves to football training. At the same time, coaches must also master the corresponding on-site guidance ability and play their own command role. In terms of the arrangement of training content, coaches should pay attention to players' psychological changes, mobilize the enthusiasm of the players as much as possible, and improve the team members' awareness of the team. They give players scientific training methods, pay attention to the content of each education, enable players absorb the essence of each training in the classroom as much as possible, and take every teaching competition seriously. They also carefully complete various preparation activities for each competition, adjust players' mentality, pay attention to their physical conditions, so as to cause adverse effects on body and mind. We should improve and promote activities that are conducive to increasing the enthusiasm of young people to participate in football and enhancing their morale, cultivate and enhance children's interest in football, get parents' support for children's participation in football, and then help to develop children's interest in football. Developing sports habits and shaping correct sports values are important innovations to promote the development of football and the healthy development of sports education cause in China.

\section{B. Rational Advice}

- The development of coaching activities of football coaches in colleges and universities should aim at popularizing football culture and improving the quality of the nation, and coaches should love sports cause, follow the laws of sports development, and put students' healthy development and social benefits at the first place.

- The innovation of the coaching work of football coaches in college and universities needs to adhere to unity and long-term planning. We should establish a level test for football skills in colleges and universities, make a reasonable and effective level test standard promotion plan, actively the support of external forces, and carry out diversified cooperative research.

- We should promote the healthy development of college football coaches' ability to coach, theoretical research and experimental research on safeguard measures, and the cooperation and support of sports system and education system. In particular, the decision-making departments of sports and education systems should strengthen coordination and give full play to the functions of management and supervision.

\section{REFERENCES}

[1] On the Development Bottleneck and Its Breakthrough in National Youth School Football Activity [J]. Li Jixia, He Zhilin, Dong Zhongming, Xu Yangcai. Journal of Shanghai University of Sport, 2012 (03). 全国青少年校园足球活动发展瓶颈及突破策略[J]. 李纪霞,何志 林,董众鸣,徐仰才.上海体育学院学报. 2012(03)

[2] Current Situation of the Development of Campus Football Coaches and Training Mode Analysis [J]. Du Fang, Liu Jiansong, Yang Jiasen. Sichuan Sports Science. 2014 (03) 校园足球教练员发展现状与培养 模式探析[J]. 杜放, 刘健松, 杨佳森. 四川体育科学. 2014(03)

[3] A Study on the Development of Campus Football Teacher Training in Shanxi Province $[\mathrm{J}]$. Wang Rui, Yang Lina, Xing Libo. Journal of Anhui Sports Science. 2017 (06). 陕西省校园足球师资培训开展状况 的研究[J]. 王瑞,杨丽娜,邢丽波. 安徽体育科技. 2017(06)

[4] Development Status and Analysis Research of Football Coach Training System in China [D]. Zeng Dan. Beijing Sport University 2009 中国足 球教练员培训体系的发展现状和分析研究 [D]. 曾丹.北京体育大学 2009

[5] Analysis of the Coaching Behavior of High-level Football Coaches in China [D]. Li Wenxiong. Hunan University of Science and Technology 2011 我国高水平足球教练员执教行为分析[D]. 李文雄.湖南科技大 学 2011

[6] Research on the Training of Excellent Youth Soccer Coaches in China [D]. Cheng Huaichun. Fujian Normal University 2008 我国优秀青少年 足球教练员岗位培训的研究[D]. 程怀春. 福建师范大学 2008

[7] The Research on the Characteristics and Developmental Countermeasures of Campus Football Teacher's Training - Taking Shanxi Province as An Example [J]. Zhang Kun, Yang Lina, Song Ying. Journal of Anhui Sports Science. 2017 (03) 校园足球师资培训特征及 发展对策研究——以陕西省为例 $[\mathrm{J}]$. 张鲲,杨丽娜, 宋莹. 安徽体育科 技. 2017(03)

[8] Research Method in Science [M]. Higher Education Press, Zhang Liwei, 2002 体育科学研究方法[M]. 高等教育出版社, 张力为[著], 2002 